\title{
Leaf Anatomy of Four Bambusa Species
}

\author{
Alin Liana ${ }^{1}$, Purnomo $^{2}$, Issirep Sumardi ${ }^{3}$, Budi Setiadi Daryono ${ }^{4}$ \\ ${ }^{1}$ Laboratory of Biology, Biology Programme, STKIP Pembangunan Indonesia, Indonesia. 90222 \\ ${ }^{2}$ Laboratory of Plant Systematics, Faculty of Biology, Universitas Gadjah Mada, Indonesia. \\ 55281 \\ ${ }^{3}$ Laboratory of Plant Structure and Development, Faculty of Biology, Universitas Gadjah Mada, \\ Indonesia. 55281 \\ ${ }^{4}$ Laboratory of Genetics and Breeding, Faculty of Biology, Universitas Gadjah Mada, Indonesia. \\ 55281 \\ \{alyn.lyana@gmail.com¹, pakkencur@yahoo.com², issirepsumardi@yahoo.co.id ${ }^{3}$, \\ bs_daryono@mail.ugm.ac.id $\left.{ }^{4}\right\}$
}

\begin{abstract}
Leaf anatomy of bamboos is known to have many representative diagnostic characters can be utilized for taxonomic purposes. This study aims to find out anatomical features that can be used as diagnostic characters in compiling systematics of Bamboo. Four species of Bambusa, namely Bambusa blumeana, Bambusa maculata, Bambusa striata, and Bambusa vulgaris were used in this study. Leaves were observed using the Light Microscope (LM) and Scanning Electron Microscope (SEM). Anatomical feature observed in the epidermis such as silica bodies, bulliform cells, stomata and three types of trichomes, namely prickles, bicellular micro hair, and peltate hair. In addition, mesophyll consisting of translucent fusoid cells and plicate cells with the number of rows and shapes varying between species.
\end{abstract}

Keywords: Bambusa, leaf anatomy, LM, SEM.

\section{Introduction}

Previous researchers have compiled bamboo classifications based on generative characters. But it is known that certain types of bamboo are rarely flowering. Therefore, taxonomists try to change the basis of classification, from generative to vegetative organs. The classification based on morphological characters of the vegetative organ is fluctuating, easily changing due to ecological factors. At the same time, taxonomists also developed anatomical studies to find the possibility of compiling classifications based on anatomical characters. Wu (1962) and Renvoize (2007) proposed an important character in the cross-section of the leaf. In more detail, Ohki (1929) in Wu (1962) reported that the character of the leaf epidermis is an important part of compiling a bamboo classification.

Furthermore, Yang et al. (2008) from China, conducted a study that emphasized the papillae character of lower leaf epidermal. Observations were made using the Scanning electron microscope (SEM) on 35 species from 12 genera, 3 of which were Bambusa. The results of this study indicate that papillae forms and distribution patterns can be used as a tool for identification between genera, 
but cannot be used for lower taxon identification. Meanwhile, the results of research by Tien et al. (2014) from Vietnam, showing differences in the papillae size of the 13 species of Schizostachyum. These results can be recommended to add anatomical character to the taxonomy of bamboo. Liana et al. (2017) Compiled the Bambusa classification in Sulawesi based on the micromorphological character of leaf epidermis.

This study aims to reveal various leaf anatomical features in Bambusa that allow it to be used in bamboo taxonomy.

\section{Material and Methods}

Samples were taken from several regions in Sulawesi, namely Bambusa blumeana from Selayar Island, Bambusa Maculata from Sangihe Island, Bambusa striata from Gorontalo, and Bambusa vulgaris from Maros.

Observation of leaf epidermis was carried out using the freehand section method and the preparation was observed using a light microscope. In addition, observations were also made by Scanning Electron Microscope (SEM) based on procedures that have been developed by Dávila \& Clark (1990) and Tien (2014) with modifications. The identification of leaf anatomical characters was also carried out by making cross-sectional preparations using the paraffin method based on the procedure developed by Johansen (1940).

\section{Results and Discussion}

The anatomical character of bamboo has an important function in classification and has been known for a long time. In 1907, Brandis examined the structure of bamboo leaves by specializing in observing the upper epidermis and lower epidermis. (Wu, 1962) summarized various studies of bamboo identification based on leaf anatomical characters. Furthermore, (Carlquist, 2010) states that anatomical properties have a great meaning in explaining the ecological and physiological conditions of a plant. Anatomical properties are also very important in taxonomic studies at various taxa levels (De Villiers, et al. 2010); (Zarrei et al. 2010); (Liu \& Zhu, 2011). Micromorphological studies of epidermal structures such as epicuticular hair, cuticle morphology, or various trichome types can provide important information in studying plant anatomical properties and taxonomic studies (Pole, 2010). Trichomes can be found in almost all plant surfaces in both vegetative (Zhou $\&$ Xia, 2012) and reproductive organs (Davies \& Stpiczyńska, 2010). Trichomes are a good object of study to answer various ecological, physiological, and systematic problems (Payne, 2006).

Furthermore, the researchers conveyed various leaf epidermal structures as diagnostic characters in bamboo identification. The character of bamboo leaf epidermis in Asia was compared with emphasis on papilla character (Yang et al. 2008). In the other hand, Zhang et al. (2014) reported that the epidermal papilla pattern of Arundinarieae leaves approached phylogenetic taxonomy. However, this does not always apply equally to different species, so it is necessary to observe each species to be able to determine the type of diagnostic character of each taxonomic group.

The following are described the characteristics of each Bambusa species that was successfully identified.

\section{Bambusa blumeana}

The surface of the upper epidermis is covered with a thick layer of the cuticle. Long rectangular cells with an average length of 22.27-107.09 $\mu \mathrm{m}$, wavy cell walls. Silica cells are found on both epidermal surfaces, rectangular in shape with walls curved inward (Fig. 1A, 1C, 1D, 1E). Prickles in the upper epidermis are rectangular at the base and pointed at the end, while in the lower 
epidermis is rounded at the base and pointed at the end, abundant in the lower epidermis (Fig. 1B, 1D, 1E). Micro hair is found on both surfaces of the epidermis (Fig. 1A, 1D). Peltate hair is found in the upper epidermis (Fig. 1A). The stomata apparatus is surrounded by four papillae; in the upper epidermis, arranged in one or two rows on each side of a vein, while the lower epidermis is arranged in two rows on each side of a vein (Fig. 1A, 1B, 1D). Bulliform cells in the upper epidermis consist of three to four cell lines, the shape of a polygonal middle cell in observing epidermal section; in observing the transverse section, the top of the row of bulliform cells protrudes to the surface, the base of which fills almost half the mesophyll space beneath it (Fig. 1C, 1E). In the transversal section, there are translucent fusoid cells, shaped horizontally, located on both sides of the vascular bundle (Fig. 1E). Plicate cells are tightly arranged, the shape varies, rectangular, some are square, consisting of two or three layers of cells; Plicate cells under translucent fusoid cells, consisting of one layer of cells (Fig. 1E).

\section{Bambusa maculata}

The surface of the lower epidermis is covered with a thick layer of cuticle. Long rectangular cells with an average length of 40.98-62.09 $\mu \mathrm{m}$, wavy cell walls. Silica cells on both epidermal surfaces are rectangular with walls curved inward (Fig. 2C, 2D, 2E). Prickles are only found in the lower epidermis, abundant (Fig. 2B, 2D, 2E). Micro hair is found on both surfaces of the epidermis. The stomata apparatus is surrounded by four papillae, in the upper epidermis arranged in one to three rows on each side of a vein, while the lower epidermis is arranged in five rows on each side of a vein (Fig 2B, 2C). Bulliform cells in the upper epidermis consist of three to five cell lines with polygonal middle cell shape at the observation of epidermal section (Fig. 2C); in observing transverse section, the upper part of the row of bulliform cells is flat, the middle part of the cell base is arranged elongated, filling more than half the parenchymal space below it (Fig. 2E). In the transverse section, there are translucent fusoid cells, surrounded by plicate cells. Plicate cells above translucent fusoid cells are tightly arranged, resembling the palisade parenchyma arrangement, consisting of three cell layers and polygonal shape; plicate cells under translucent fusoid cells are polygonal in shape and consist of one layer of cells (Fig. 2E). 

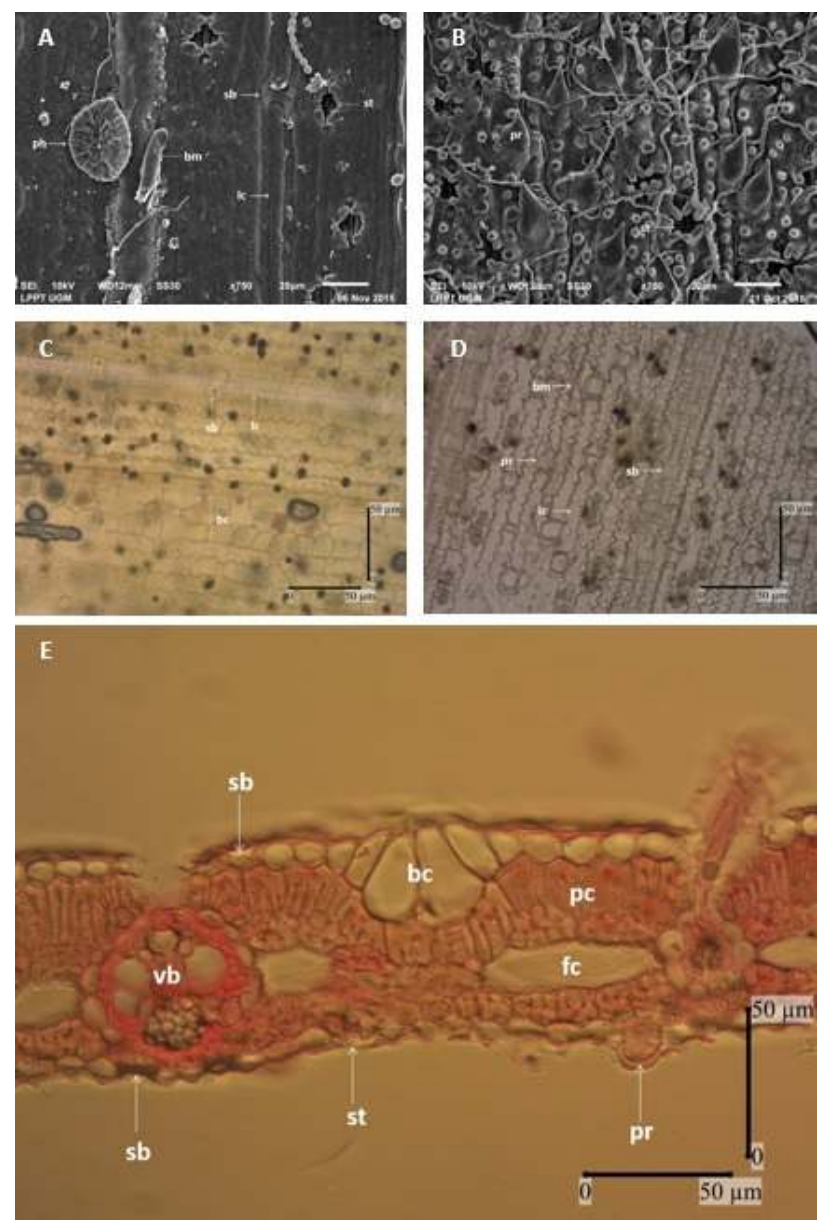

Figure 1. Bambusa blumeana. Upper epidernfisgusing.SFaxhbusa maculata. Upper epidermis using SEM (A), lower epidermis using SEM (B), upper (A)inddawisr epidermis using SEM (B), upper epidermis using LM (C), lower epidermis using LM (Dy,sirngłsher (C), lower epidermis using LM (D), transverse section (E). Abbreviations: bm: bicellular miseothamr( $(\mathrm{B})$ : Abbreviations: bm: bicellular micro hair; sb: silica bodies; st: stomata; ph: peltate hair; lcslbing bolliess:st: stomata; ph: peltate hair; lc: long cell; pr: prickles; bc: bulliform cells; pc: plicate cells,pfiaclikessildc: bulliform cells; pc: plicate cells, fc: fusoid cells; vb: vascular bundle. cells; vb: vascular bundle. 

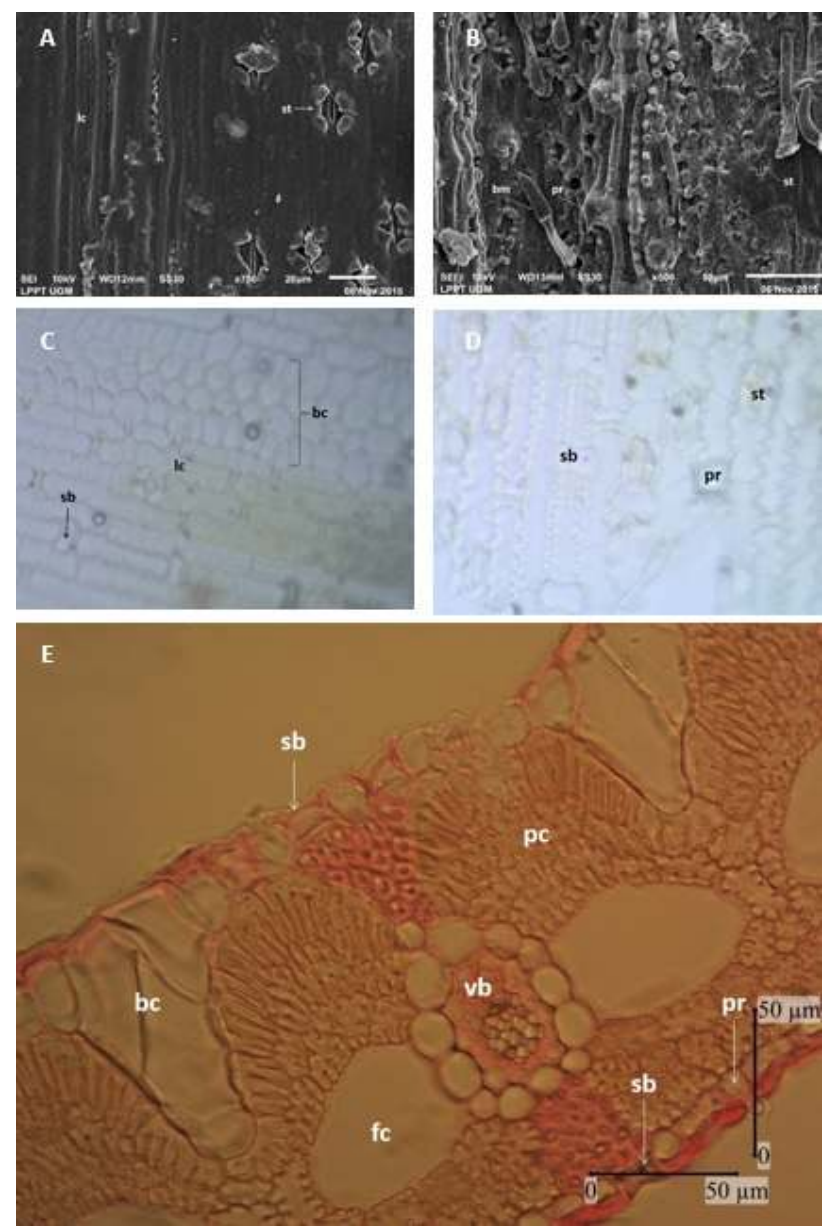

\section{Bambusa striata}

Both epidermal surfaces are covered with a thick layer of cuticle. The lower epidermis is roughened with numerous cuticular papillae. Long cell with an average length of 24.71-31.87 $\mu \mathrm{m}$, the cell wall is wavy, with the middle part filled with papillae. Silica cells with rectangular in shape and inward-curved walls, found on both surfaces of the epidermis (Fig. 3A - 3E). Prickles are found in abundant amounts of the lower epidermis (Fig. 3B, 3D). Micro hair is found on both surfaces of the epidermis (Fig. 3A, 3B, 3D). The stomata apparatus is surrounded by four papillae, in the upper epidermis arranged in one to two rows on each side of a vein, while in the lower epidermis arranged in three rows on each side of a vein (Fig. 3C, 3D). Bulliform cells in the upper epidermis consist of three to four cell lines. In observing the epidermal section of the middle cell form extending (Fig. 3C). In observing the transverse section, the upper part of the cell line protrudes to the surface, while the base part fills half of the mesophyll below (Fig. 3E). The transverse section, there are translucent fusoid cells that form horizontally extending, surrounded by plicate cells. Plicate cells at the top of translucent fusoid cells are closely arranged to resemble palisade parenchyma, which can consist of one or two layers of cells; whereas plicate cells under translucent fusoid cells are polygonal, consisting of one layer of cells (Fig. 3E). 

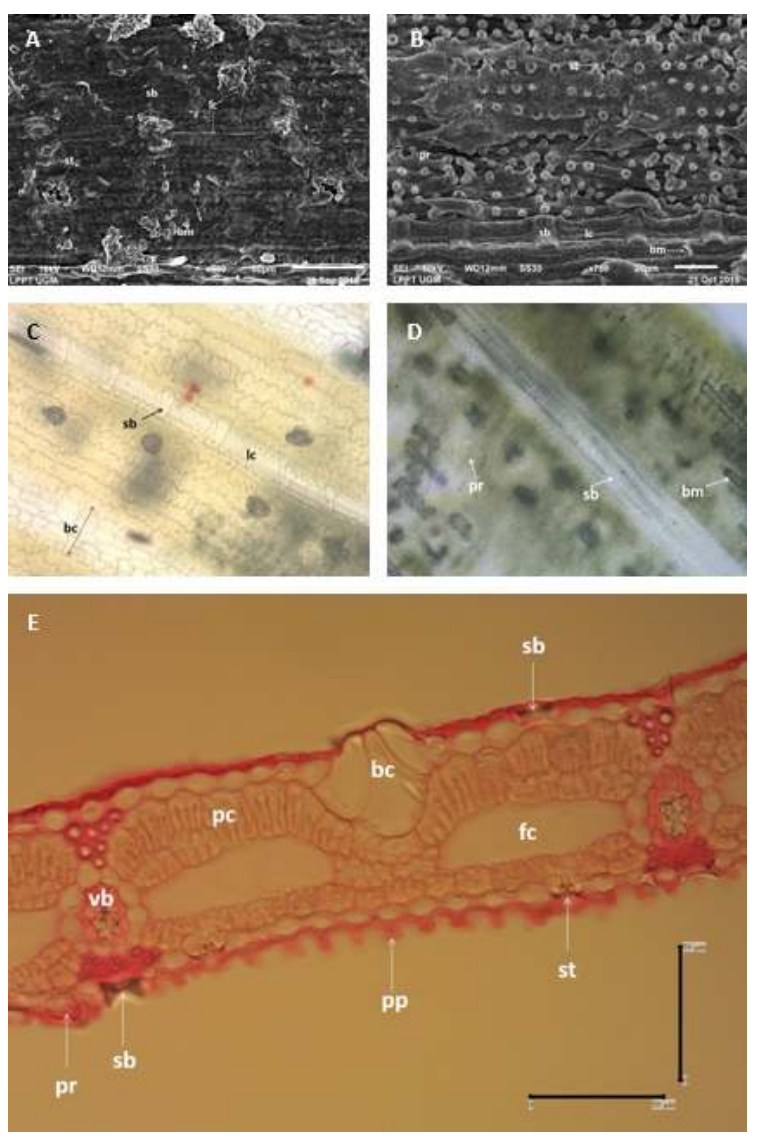

Figure 3. Bambusa striata. Upper epidermis using SEM (A), lower epidermis using SEM (B), upper epidermis using LM (C), lower epidermis using LM (D), transverse section (E). Abbreviations: bm: bicellular micro hair; sb: silica bodies; st: stomata; ph: peltate hair; lc: long cell; pr: prickles; bc: bulliform cells; pc: plicate cells, fc: fusoid cells; vb: vascular bundle; pp: papillae.
Figure 4. Bambusa vulgaris. Upper epidermis using SEM (A), lower epidermis using SEM (B), upper epidermis using LM (C), lower epidermis using LM (D), transverse section (E). Abbreviations: bm: bicellular micro hair; sb: silica bodies; st: stomata; ph: peltate hair; lc: long cell; pr: prickles; bc: bulliform cells; pc: plicate cells, fc: fusoid cells; vb: vascular bundle. 

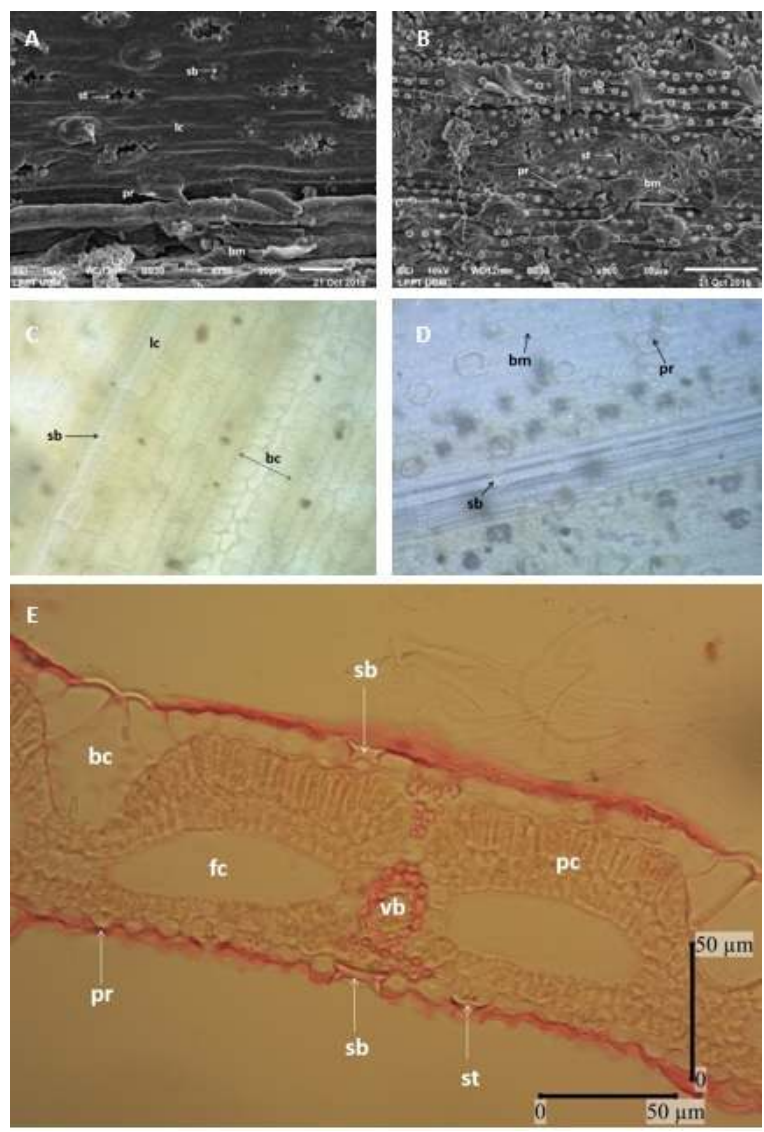

\section{Bambusa vulgaris}

Both epidermal surfaces are covered with a thick layer of cuticle. The lower epidermis is roughened with numerous cuticular papillae (Fig. 4B, 4E). Long cell with an average length of 31.42-93.81 $\mu \mathrm{m}$, wavy cell walls. Silica cells are found in the upper and the lower epidermis is rectangular with walls curved inward (Fig. 4A - 4E). Prickles and micro hair are also found on both surfaces of the epidermis (Fig. 4A, 4B, 4D). The stomata apparatus is surrounded by four papillae, in the upper epidermis arranged in two to four rows on each side of a vein, while the lower epidermis is arranged in four rows on each side of a vein (Fig. 4B, 4C). Bulliform cells in the upper epidermis consist of three to five cell lines. On observation with the epidermal section, the middle cell shape extends (Fig. 4C). In observing the transverse section, the top of the row of bulliform cells is arranged to protrude to the surface, and the base part fills the mesophyll space beneath it (Fig. 4E). Translucent fusoid cells are horizontally elongated, surrounded by plicate cells. Plicate cells at the top of the translucent fusoid cells are tightly arranged, resembling the arrangement of palisade parenchyma, consisting of two layers of cells; whereas plicate cells at the bottom of translucent fusoid cells are polygonal, consisting of one layer of cells (Fig. 4E).

Based on observations of leaf epidermis in the samples studied, various anatomical characters can be described as follows. There are three types of trichomes in the epidermis which were observed from four species observed, namely: prickles, micro hair, and peltate hair. In addition, in the leaf epidermis, there are also silica cells, bulliform cells, and stomata. Prickles are found in the 
upper and lower epidermis. The shape of the prickles in the upper epidermis varies, B. blumeana prickles are rectangular with a pointed tip, while $B$. vulgaris is short round with a pointed tip. In observing the lower epidermis, prickles were found in all Bambusa samples. The shape of the prickles in the lower epidermis is generally round at the base and sharp at the end. Prickles are unicellular, wide at the bottom and sharp at the top, growing upwards (Ellis, 2015). Generally thinwalled can be found in upper and lower leaf (Renvoize, 2007); (Wu, 1962). (Gomes \& Neves, 2009) explains that prickles in the lower epidermis are evenly distributed.

Generally, micro hairs that are observed have the same shape but vary in size. Micro hair consists of two long cells, the free upper cell with a base attached to the cell below. These cells are shaped like thin filaments. Micro hair was found in the epidermis over all Bambusa species observed. Micro hair consists of two very thin and easily shed walled cells (Tateoka et al. 2015). Although the shape is relatively similar, the quantitative size and nature can be a differentiator between species (Wu, 1962). Based on the results of the above observations, micro hair can be an important diagnostic character in Bambusa's identification. The presence or absence of micro hair in the leaf epidermis can be used to clearly distinguish Poaceae groups (Soderstrom, 2006). However, (Gomes \& Neves, 2009) confirms that micro hair is not recommended to distinguish species. Micro hair can be a diagnostic character at the higher genus and taxa level. Peltate hair is found in the upper epidermis of $B$. blumeana leaves. This trichome is attached like scales (not stemmed), disc-shaped, consisting of long branched cells arranged in a circle. Peltate hair is a multicellular trichome, generally consisting of a short stem and a flat plate (Ascensão et al. 1995). Each bulkhead on the disk is a single cell. This type of trachoma generally stores secretory fluids to protect plants from the threat of external factors.

Generally, members of the Poaceae family have the bulliform cell. The shape, size, and disposition of bulliform cells can be used for the purpose of classification and identification (Cutler et al., 1939). The Bambusa species observed has various types of bulliform cells, the number of cell lines can be three to five. On the surface observation, the middle cell shape can be polygonal or elongated. The results of observations of the transverse section indicate variations in the type of upper part of the bulliform cell row, some of which are protruding, flat or drowned; while for the base of the bulliform cell, there is one third, half, or even more than half of the mesophyll below. Based on the structure, it is known that the four Bambusa species studied, each of which has a different bulliform cell character. Thus the bulliform cell structure is a diagnostic character in distinguishing members of the Bambusa.

In addition to observing leaf epidermis, observations of the transverse section also found characteristic structures in bamboo mesophiles, namely translucent fusoid cells and plicate cells. Plicate cells at the top of the fusoid cell are tightly arranged and neat, consisting of two or three rows; while plicate cells at the bottom of fusoid cells are polygonal and consist of one or two layers of cells. Translucent fusoid cells are located flanking the vascular bundle, and not under the bulliform cells. B. maculata has plicate cells and translucent fusoid cells that are different among all the samples studied. Plicate cells of $B$. maculata cells are arranged in three layers of cells above and two layers of cells under translucent fusoid cells. If you follow the pattern made by Wu (1962), B. maculata forms a 3: 2 pattern, while the other species are patterned 2: 1 . According to $\mathrm{Wu}$ (1962), the character of plicate cells and translucent fusoid cells causes the bamboo to be placed in a separate taxon in Poaceae.

\section{Conclusion}

Anatomical feature observed in the epidermis such as silica bodies, bulliform cells, stomata and three types of trichomes, namely prickles, bicellular micro hair, and peltate hair. In addition, mesophyll consisting of translucent fusoid cells and plicate cells with the number of rows and 
shapes varying between species. The anatomical features that can be used to distinguish four species observed are the Bulliform cell structure, peltate hair, and the plicate cell pattern.

\section{Acknowledgements}

The authors are grateful to Mrs. Prapti, Laboratory of Plant Structure and Development, Faculty of Biology, Universitas Gadjah Mada for her skillful technical assistance in sample preparations.

\section{References}

[1] Ascensão, L., Marques, N., \& Pais, M. S. Glandular trichomes on vegetative and reproductive organs of Leonotis leonurus (Lamiaceæ). Annals of Botany. https://doi.org/10.1006/anbo.1995.1067 (1995)

[2] Carlquist, S. Caryophyllales: A key group for understanding wood anatomy character states and their evolution. Botanical Journal of the Linnean Society. https://doi.org/10.1111/j.1095-8339.2010.01095.x (2010)

[3] Davies, K. L., \& Stpiczyńska, M. Structure and distribution of floral trichomes in Lycaste and Sudamerlycaste (Orchidaceae: Maxillariinae s.1.). Botanical Journal of the Linnean Society. https://doi.org/10.1111/j.1095-8339.2010.01091.x (2010)

[4] De Villiers, B. J., Tilney, P. M., \& Van Wyk, B. E. The taxonomic significance of leaf anatomical characters in Cussonia and related genera (Araliaceae). Botanical Journal of the Linnean Society. https://doi.org/10.1111/j.1095-8339.2010.01085.x (2010)

[5] Ellis, R. P. A procedure for standardizing comparative leaf anatomy in the Poaceae. II. The epidermis as seen in surface view. Bothalia, 12(4), 641-671. https://doi.org/10.4102/abc.v12i4.1441(2015)

[6] Gomes, D. M. S., \& Neves, L. de J. Scanning electron microscopy of the leaf epidermis of Merostachys Spreng. (Poaceae: Bambusoideae). Acta Botanica Brasilica, 23(2), 516525. https://doi.org/10.1590/s0102-33062009000200023 (2009)

[7] Liana, A., Purnomo, P., Sumardi, I., \& Daryono, B. The Classification of Bambusa spp. from Celebes Based on the Micromorphological Characters of Leaf Epidermis. Journal of Tropical Life Science, 7(3), 197-207. https://doi.org/10.11594/jtls.07.03.02 (2017)

[8] Liu, W., \& Zhu, X. Y. Leaf epidermal characters and taxonomic revision of Schizophragma and Pileostegia (Hydrangeaceae). Botanical Journal of the Linnean Society. https://doi.org/10.1111/j.1095-8339.2010.01101.x (2011)

[9] Payne, W. W. A Glossary of Plant Hair Terminology. Brittonia. https://doi.org/10.2307/2806659 (2006)

[10] Pole, M. Cuticle morphology of Australasian Sapindaceae. Botanical Journal of the Linnean Society. https://doi.org/10.1111/j.1095-8339.2010.01086.x (2010)

[11] Renvoize, S. A. A Survey of Leaf-Blade Anatomy in Grasses X: Bambuseae. Kew Bulletin. https://doi.org/10.2307/4109902 (2007)

[12] Soderstrom, T. R. Some Evolutionary Trends in the Bambusoideae (Poaceae). Annals of the Missouri Botanical Garden. https://doi.org/10.2307/2398809 (2006)

[13] Tateoka, T., Inoue, S., Kawano, S., Gazette, S. B., \& Dec, N. Notes on Some Grasses . IX. Systematic Significance of Bicellular Microhairs of Leaf Epidermis or nuclei with one of the two nutri-heterocaryon nuclei were identified three of four from diploids clei from the inclusion forces from the heterocaryons genotypes. 121(2), 80-91. (2015)

[14] Tien, T. Van, Nghia, N. H., \& Xia, and N. Micromorphological study on the leaf 
epidermis of Schizostachyum nees from Vietnam. Vietnam Journal of Forest Science, 2. Retrieved from http://vafs.gov.vn/en/2014/07/micromorphological-study-on-theleaf-epidermis-of-schizostachyum-nees-from-vietnam/ (2014)

[15] Wu, C. Y. The classification of Bambuseae based on leaf anatomy. Botanical Bulletin of Academia Sinica, Vol. 3, pp. 83-108. (1962)

[16] Yang, H. Q., Wang, H., \& Li, D. Z. Comparative morphology of the foliage leaf epidermis, with emphasis on papillae characters, in key taxa of woody bamboos of the Asian tropics (Poaceae: Bambusoideae). Botanical Journal of the Linnean Society. https://doi.org/10.1111/j.1095-8339.2007.00736.x (2008)

[17] ZARREI, M., WILKIN, P., INGROUILLE, M. J., ZARRE, S., \& CHASE, M. W. The systematic importance of anatomical data in Gagea (Liliaceae) from the Flora Iranica area. Botanical Journal of the Linnean Society. https://doi.org/10.1111/j.10958339.2010.01081.x (2010)

[18] Zhang, Y. X., Zeng, C. X., \& Li, D. Z. Scanning electron microscopy of the leaf epidermis in Arundinarieae (Poaceae: Bambusoideae): Evolutionary implications of selected micromorphological features. Botanical Journal of the Linnean Society, 176(1), 46-65. https://doi.org/10.1111/boj.12192 (2014)

[19] Zhou, W., \& Xia, N. H. Leaf epidermal features of Lithocarpus (Fagaceae) from China and their systematic significance. Botanical Journal of the Linnean Society. https://doi.org/10.1111/j.1095-8339.2011.01196.x (2012) 